\title{
PERFORMANCE OF LATERITIC CONCRETE UNDER ENVIRONMENTAL HARSH CONDITION
}

\author{
Olubisi A. Ige \\ Department of Civil Engineering, Osun State Polytechnic, Iree.bisiige@gmail.com.
}

\begin{abstract}
This is an investigation of weathering characteristics of Laterized concrete with laterite-fine aggregate ratio as a factor. It was done with a view of ascertaining the suitability of laterite as aggregate substitutes at $0,10,20,30$ and $40 \%$ of fine aggregate used in the construction industry. The weathering characteristics were examined by conditioning laterized concrete cubes to varying temperatures, chemical and alternate wetting and drying, which all represent the operating weather conditions (wet and dry seasons) in tropics, including Nigeria. The mix proportion used was 1:2:4, the curing age of the laterized concrete was based on 28days curing age, while the compressive strength of the treated laterized concrete cubes was determined. The result of this research showed that the compressive strength of laterized concrete with laterite-fine aggregate ratio variation decreases when subjected to alternate wetting and drying and increases when subjected to magnesium sulphate $\left(\mathrm{Mg}_{2} \mathrm{SO}_{4}\right)$. It was also discovered that a laterized concrete with a laterite-fine aggregate ratio of $20 \%$ conditioned to a temperature range of $100^{\circ} \mathrm{C}$ attained optimum compressive strength of $12.90 \mathrm{Nmm}^{-2}$
\end{abstract}

Keywords: Laterized Concrete, Comprehensive strength, Weathering Characteristics.

\section{INTRODUCTION}

Large areas in the tropical and subtropical regions of the world are covered by lateritic formations, which include soil and concretions. Soil and concretions, which are latter being the lateritic aggregate, are components, which are widely used for civil engineering purposes. In construction industry, the most widely used material is concrete which is obtained by mixing cementitious materials, water and aggregates. The mixture when placed in forms and allowed to cure hardens into a rocklike mass known as hardened concrete. The hardening is caused by chemical reaction between water and cement and it continues for a long time. It may also be considered as an artificial stone in which the voids of larger particles (coarse aggregate) are filled by the smaller particles (fine aggregates) and the voids of fine aggregates are filled with cement. The strength, durability and other characteristics of concrete depend upon the properties of its ingredients, on the proportions of mix, the method of compaction and other controls during placing, and curing.

Nowadays, with the advancement of technology, a lot of researches have been carried out to discover the new concrete technology. Hasniza [1] noted that in accordance with the Ninth Malaysian plan, government also encourages publics to be involved in the Research and Development (R \& D) in construction industry. One of the researches done in concrete technology is a study to find any material that can be used as a replacement material in concrete mixture [2]. The materials that show any likely potential to be used as a replacement material such as steel, latex, quarry dust, lateritic soil and glass are being investigated. This research is important to construction industry because it is not only possible if the conventional raw material such as sand and granite (aggregate) used in concrete mix will run out, but the research also will cut down the cost of construction [3].

In this study, the focus will give more to the research about laterite soil used as an aggregate substitute in the concrete mixture. Usually, the normal concrete contains cement, fine aggregate (sand) and coarse aggregate (granite). However, for this study granite will serve as coarse aggregate and then laterite soil will be added into the mixture in certain percentage of sand (fine aggregate). This present study, which studies the performance of lateritic concrete under environmental harsh condition, form part of the efforts aimed at fully integrating laterized concrete for structural use in construction works. This was done by subjecting laterized concrete to varying temperatures, chemicals such as magnesium sulphate $(\mathrm{Mg} 2 \mathrm{SO} 4)$ and alternate wetting and drying, while still varying laterite-sharp sand ratio as fine aggregate.

\section{RESEARCH METHODOLOGY}

The lateritic soil used was obtained from a nearby borrow pit at the Faculty of Science, Osun State Polytechnic, Iree. The material was air dried and a sample was subjected to sieve analysis using the manual sieve shaker with sieves BS No 4, 8, $16,20,40,70,100$ and 200. The granite (coarse) and sand 
(fine aggregates) used were obtained from a construction site along Iree - Eripa road, Osun State Nigeria and found to be suitable as specified by [4]. The cement used for this experiment was the Ordinary Portland Cement in accordance to [5] produced by the West African Portland Cement Company, Nigeria. It is the brand widely used in the construction industry and also readily available. A potable water free from impurities in compliance with [6] was used in carrying out the experiment. The water-cement ratio used for the project was based on the optimum water-cement ratio given by [7] and [8].

\subsection{Production of Cubes}

Batching of materials was done by weight using semi automatic scale at the $20 \mathrm{~kg}$ range. The manual method of mixing, using shovels and trowels, was adopted while the mix ratio used was 1:2:4. The sand-laterite ratio used as fine aggregate were $0,10,20,30$, and $40 \%$, this was to ascertain the range of combination that will give optimum compressive strength [9]. The mixing was done such that the dry components were mixed until a satisfactory uniform colour was obtained with desired water being added gradually to the mixed dry components and thorough mixing done to give a workable concrete [10]. The moulds (150 x $150 \times 150) \mathrm{mm} 3$ were used in casting the cubes. Four replicates were made for each laterite-aggregate ratio variation. The curing of cubes was based on 28 days curing age using the curing tank located at civil engineering department of Osun State Polytechnic, Iree.

Two of the four replicates of the cured cubes for each ratio variation of $0,10,20,30$ and $40 \%$, respectively were subjected to temperature of 50 and $100 \mathrm{oC}$ for two hours using an oven. The temperature treatment continued in this trend for each of the ratio variations. The temperature was applied to subject the specimens to the dry season, which operates in the tropics.

One of the remaining three replicates of the cured cubes was subjected to alternate wetting and drying. This was done such that replicates were first dried at $50 \mathrm{oC}$ for 2 hours (because in recent times the highest temperature recorded in Nigeria was $400 \mathrm{C}, 50 \mathrm{oC}$ was thus used to give allowance for any possible increment) and then immersed in water at room temperature for 1 hour. These were repeated in three cycles, making use of the drying oven. The alternate wetting and drying was done to subject the specimens to factors of weathering (i.e. rainy and dry seasons) that are operating in the tropics. Others were subjected to chemical such as magnesium sulphate (Mg2SO4) to determine its performance under environmental harsh condition.

\subsection{Crushing of Cubes}

After each cube had been subjected to the desired conditions, their crushing loads were determined using the AveryDenilson Testing Machine. The cubes were weighed before crushing to facilitate the determination of densities.

\section{RESULTS AND DISCUSSION}

\subsection{Sieve Analysis}

The results of sieve analysis of the laterite used are shown in table 1.1 and the grading curve is also shown in chat 1 . Analysis of the results showed that the laterite used in this experiment is well graded.

Table 1: Results of Sieve Analysis of Laterite

\begin{tabular}{|l|l|l|l|l|l|l|}
\hline Sieve No & $\begin{array}{l}\text { Sieve } \\
\text { Opening }\end{array}$ & $\begin{array}{l}\text { Weight of } \\
\text { Sieve (g) }\end{array}$ & $\begin{array}{l}\text { Weight of } \\
\text { Sieve + soil (g) }\end{array}$ & $\begin{array}{l}\text { Weight of soil } \\
\text { Retained (g) }\end{array}$ & Retained (\%) & Passing (\%) \\
\hline 4 & 4.760 & 400 & 650 & 250 & 18.12 & 81.88 \\
\hline 8 & 2.360 & 1000 & 1400 & 400 & 28.99 & 52.89 \\
\hline 16 & 1.180 & 400 & 500 & 100 & 7.25 & 45.64 \\
\hline 20 & 0.850 & 350 & 600 & 250 & 18.12 & 27.52 \\
\hline 40 & 0.425 & 350 & 480 & 130 & 9.42 & 18.10 \\
\hline 70 & 0.212 & 300 & 350 & 50 & 3.62 & 14.48 \\
\hline 100 & 0.150 & 280 & 300 & 20 & 1.45 & 13.03 \\
\hline 200 & 0.075 & 220 & 250 & 30 & 2.17 & 10.86 \\
\hline Rec Pan & - & 500 & 650 & 150 & 10.87 & - \\
\hline
\end{tabular}

Type of Soil: Laterite, Total weight: 1380g. 
The observed crushing loads of the cubes for laterite- fine aggregate ratio variation of $0,10,20,30$ and $40 \%$, magnesium sulphate $(\mathrm{Mg} 2 \mathrm{SO} 4)$ and alternate wetting and drying respectively are shown below. The observed values are temperature, volume, effective area, weight and crushing load of each cube, which had been subjected to desired conditions. The analyses are as represented in Tables 2 to 8 under column headings weight, density, crushing load and compressive strength.

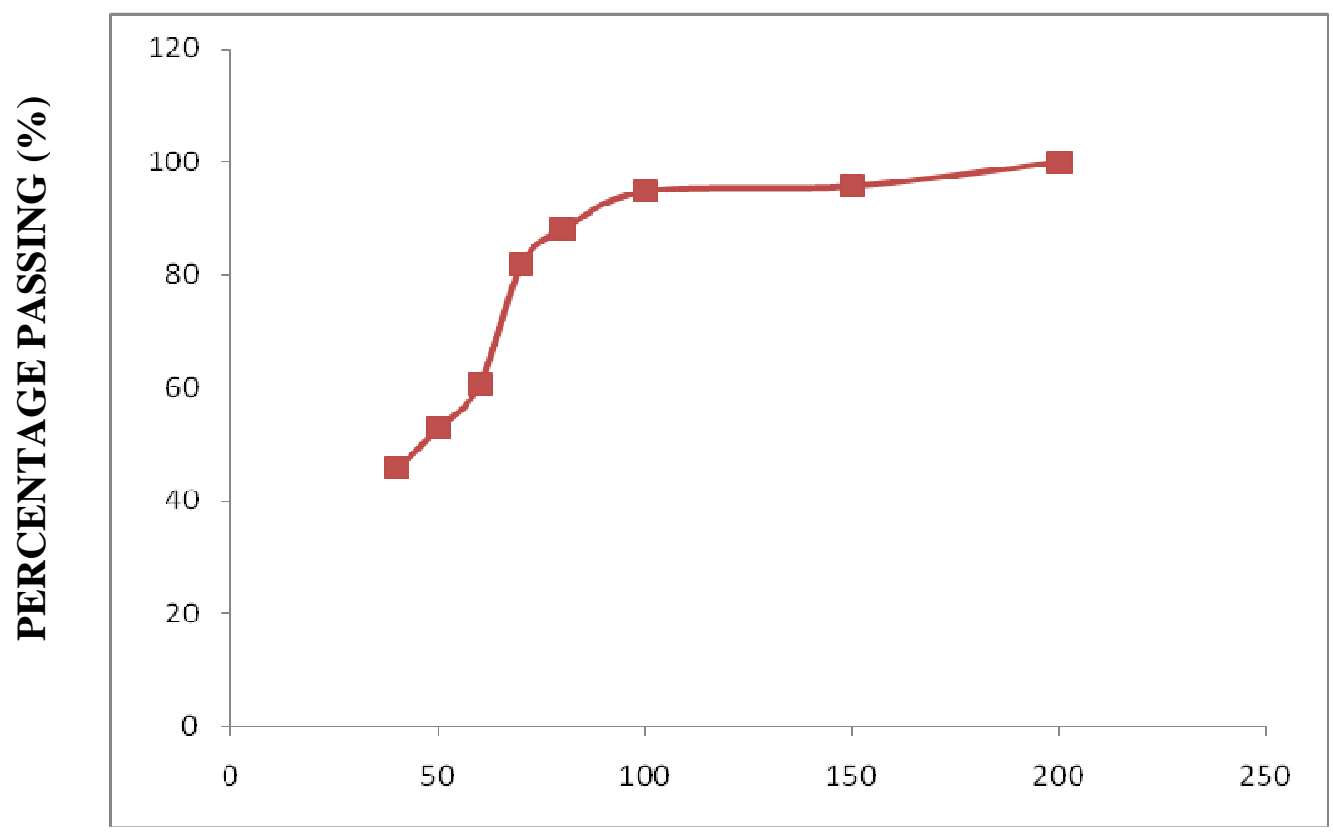

SIEVE SIZE $(\mu \mathrm{m})$

Chart 1: Grading Curve of Sieve Analysis of Laterite Soil

Table 2: Compressive strength and density of laterized concrete at $0 \%$ laterite-fine ratio

\begin{tabular}{|l|l|l|l|l|l|l|}
\hline Temperature $\left({ }^{\mathbf{0}} \mathbf{C}\right)$ & $\begin{array}{l}\text { Weight } \\
(\mathbf{k g})\end{array}$ & $\begin{array}{l}\text { Volume } \\
\left(\mathbf{m}^{\mathbf{3}}\right)\end{array}$ & $\begin{array}{l}\text { Density } \\
\left(\mathbf{K N} / \mathbf{m}^{\mathbf{3}}\right)\end{array}$ & $\begin{array}{l}\text { Crushing } \\
\text { load } \mathbf{( K N})\end{array}$ & $\begin{array}{l}\text { Effective } \\
\text { area } \\
\left(\mathbf{m m}^{\mathbf{2}}\right)\end{array}$ & $\begin{array}{l}\text { Compressive } \\
\text { Strength } \\
\left(\mathbf{N} / \mathbf{m m}^{\mathbf{2}}\right)\end{array}$ \\
\hline 50 & 8.10 & $0.15^{3}$ & 23.08 & 320 & $150^{2}$ & 14.22 \\
\hline 100 & 8.08 & $0.15^{3}$ & 23.02 & 317 & $150^{2}$ & 14.09 \\
\hline
\end{tabular}

Table 3: Compressive strength and density of laterized concrete at 10\% laterite-fine ratio

\begin{tabular}{|l|l|l|l|l|l|l|}
\hline Temperature $\left({ }^{\mathbf{o}} \mathbf{C}\right)$ & $\begin{array}{l}\text { Weight } \\
(\mathbf{k g})\end{array}$ & $\begin{array}{l}\text { Volume } \\
\left(\mathbf{m}^{\mathbf{3}}\right)\end{array}$ & $\begin{array}{l}\text { Density } \\
\left(\mathbf{K N} / \mathbf{m}^{\mathbf{3}}\right)\end{array}$ & $\begin{array}{l}\text { Crushing } \\
\text { load }(\mathbf{K N})\end{array}$ & $\begin{array}{l}\text { Effective } \\
\text { area } \\
\left(\mathbf{m m}^{\mathbf{2}}\right)\end{array}$ & $\begin{array}{l}\text { Compressive } \\
\text { Strength } \\
\left(\mathbf{N} / \mathbf{m m}^{\mathbf{2}}\right)\end{array}$ \\
\hline 50 & 7.69 & $0.15^{3}$ & 21.91 & 290 & $150^{2}$ & 12.90 \\
\hline 100 & 7.67 & $0.15^{3}$ & 21.85 & 285 & $150^{2}$ & 12.60 \\
\hline
\end{tabular}

Table 4: Compressive Strength and density of laterized concrete at $20 \%$ laterite- fine ratio

\begin{tabular}{|l|l|l|l|l|l|l|}
\hline Temperature $\left({ }^{\mathbf{0}} \mathbf{C}\right)$ & $\begin{array}{l}\text { Weight } \\
(\mathbf{k g})\end{array}$ & $\begin{array}{l}\text { Volume } \\
\left(\mathbf{m}^{\mathbf{3}}\right)\end{array}$ & $\begin{array}{l}\text { Density } \\
\left(\mathbf{K N} / \mathbf{m}^{\mathbf{3}}\right)\end{array}$ & $\begin{array}{l}\text { Crushing } \\
\text { load }(\mathbf{K N})\end{array}$ & $\begin{array}{l}\text { Effective } \\
\text { area } \\
\left(\mathbf{m m}^{\mathbf{2}}\right)\end{array}$ & $\begin{array}{l}\text { Compressive } \\
\text { Strength } \\
\left(\mathbf{N} / \mathbf{m m}^{\mathbf{2}}\right)\end{array}$ \\
\hline 50 & 7.77 & $0.15^{3}$ & 22.14 & 280 & $150^{2}$ & 12.40 \\
\hline 100 & 7.70 & $0.15^{3}$ & 21.94 & 290 & $150^{2}$ & 12.90 \\
\hline
\end{tabular}


Table 5: Compressive strength and density of laterized concrete at 30\% laterite- fine ratio.

\begin{tabular}{|l|l|l|l|l|l|l|}
\hline Temperature $\left({ }^{\mathbf{0}} \mathbf{C}\right)$ & $\begin{array}{l}\text { Weight } \\
(\mathbf{k g})\end{array}$ & $\begin{array}{l}\text { Volume } \\
\left(\mathbf{m}^{\mathbf{3}}\right)\end{array}$ & $\begin{array}{l}\text { Density } \\
\left(\mathbf{K N} / \mathbf{m}^{\mathbf{3}}\right)\end{array}$ & $\begin{array}{l}\text { Crushing } \\
\text { load }(\mathbf{K N})\end{array}$ & $\begin{array}{l}\text { Effective } \\
\text { area } \\
\left(\mathbf{m m}^{\mathbf{2}}\right)\end{array}$ & $\begin{array}{l}\text { Compressive } \\
\text { Strength } \\
\left(\mathbf{N} / \mathbf{m m}^{\mathbf{2}}\right)\end{array}$ \\
\hline 50 & 8.05 & $0.15^{3}$ & 22.93 & 220 & $150^{2}$ & 9.8 \\
\hline 100 & 8.02 & $0.15^{3}$ & 22.85 & 200 & $150^{2}$ & 8.8 \\
\hline
\end{tabular}

Table 6: Compressive strength and density of laterized concrete at $40 \%$ laterite- fine ratio.

\begin{tabular}{|l|l|l|l|l|l|l|}
\hline Temperature $\left({ }^{\mathbf{0}} \mathbf{C}\right)$ & $\begin{array}{l}\text { Weight } \\
(\mathbf{k g})\end{array}$ & $\begin{array}{l}\text { Volume } \\
\left(\mathbf{m}^{\mathbf{3}}\right)\end{array}$ & $\begin{array}{l}\text { Density } \\
\left(\mathbf{K N} / \mathbf{m}^{\mathbf{3}}\right)\end{array}$ & $\begin{array}{l}\text { Crushing } \\
\text { load }(\mathbf{K N})\end{array}$ & $\begin{array}{l}\text { Effective } \\
\text { area } \\
\left(\mathbf{m m}^{\mathbf{2}}\right)\end{array}$ & $\begin{array}{l}\text { Compressive } \\
\text { Strength } \\
\left(\mathbf{N} / \mathbf{m m}^{\mathbf{2}}\right)\end{array}$ \\
\hline 50 & 8.18 & $0.15^{3}$ & 23.30 & 190 & $150^{2}$ & 8.4 \\
\hline 100 & 8.10 & $0.15^{3}$ & 23.08 & 200 & $150^{2}$ & 8.8 \\
\hline
\end{tabular}

Table 7: Compressive strength and density of laterized concrete subjected to magnesium sulphate $\left(\mathrm{Mg}_{2} \mathrm{SO}_{4}\right)$.

\begin{tabular}{|c|c|c|c|c|c|c|c|c|}
\hline \multirow{2}{*}{$\begin{array}{l}\text { Ratio } \\
\text { variation } \\
(\%) \\
0\end{array}$} & $\begin{array}{l}\text { Weigh } \\
\text { Initial }\end{array}$ & $\begin{array}{l}\text { (kg) } \\
\text { Final }\end{array}$ & $\begin{array}{l}\text { Volume } \\
\left(\mathbf{m}^{3}\right)\end{array}$ & \multicolumn{2}{|c|}{$\begin{array}{l}\text { Density }\left(\mathrm{KN} / \mathrm{m}^{3}\right. \\
\text { Initial Final }\end{array}$} & \multirow{2}{*}{$\begin{array}{l}\begin{array}{l}\text { Crushing } \\
\text { load } \\
(\mathbf{K N})\end{array} \\
330\end{array}$} & \multirow{2}{*}{$\begin{array}{l}\text { Effective } \\
\text { area } \\
\left(\mathbf{m m}^{\mathbf{2}}\right) \\
150^{2}\end{array}$} & \multirow{2}{*}{$\begin{array}{l}\text { Compressive } \\
\text { strength } \\
\left(\mathbf{N} / \mathbf{m m}^{2}\right)\end{array}$} \\
\hline & 8.40 & 8.37 & $0.15^{3}$ & $23 . .93$ & 23.85 & & & \\
\hline 10 & 8.32 & 8.43 & $0.15^{3}$ & 23.70 & 24.02 & 310 & $150^{2}$ & 13.78 \\
\hline 20 & 7.98 & 7.85 & $0.15^{3}$ & 22.74 & 22.36 & 320 & $150^{2}$ & 14.22 \\
\hline 30 & 7.90 & 7.94 & $0.15^{3}$ & 22.51 & 22.62 & 290 & $150^{2}$ & 12.90 \\
\hline 40 & 8.05 & 8.01 & $0.15^{3}$ & 22.93 & 22.82 & 220 & $150^{2}$ & 9.80 \\
\hline
\end{tabular}

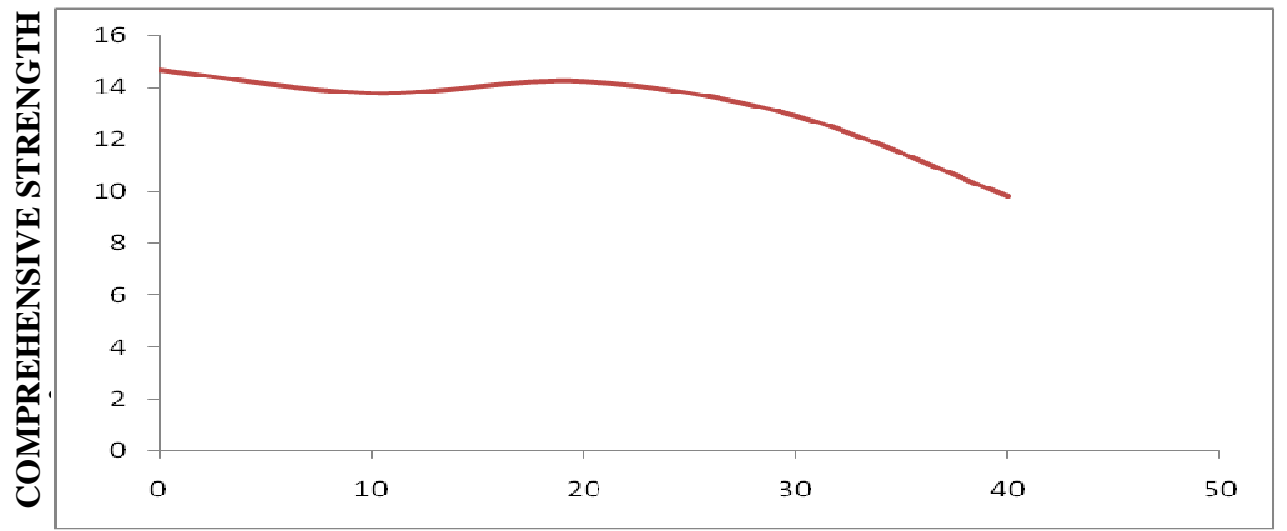

LATERITE- FINE AGGREGATE RATIO (\%)

Chart 2: Effect of magnesium sulphate $\left(\mathrm{Mg}_{2} \mathrm{SO}_{4}\right)$ on the compressive strength of laterized concrete

Table 8: Compressive strength and density of laterized concrete subjected to alternate wetting and drying

\begin{tabular}{|c|c|c|c|c|c|c|c|c|}
\hline $\begin{array}{l}\text { Ratio } \\
\text { variation } \\
(\%)\end{array}$ & $\begin{array}{l}\text { Weigh } \\
\text { Initial }\end{array}$ & $\begin{array}{l}\text { (kg) } \\
\text { Final }\end{array}$ & $\begin{array}{l}\text { Volume } \\
\left(\mathbf{m}^{3}\right)\end{array}$ & $\begin{array}{l}\text { Densit } \\
\text { Initial }\end{array}$ & $\begin{array}{l}\mathrm{KN} / \mathrm{m}^{3} \\
\text { inal }\end{array}$ & $\begin{array}{l}\text { Crushing } \\
\text { load } \\
(\mathrm{KN})\end{array}$ & $\begin{array}{l}\text { Effective } \\
\text { area } \\
\left(\mathbf{m m}^{2}\right)\end{array}$ & $\begin{array}{l}\text { Compressive } \\
\text { strength } \\
\left(\mathrm{N} / \mathrm{mm}^{2}\right)\end{array}$ \\
\hline 0 & 8.10 & 8.15 & $0.15^{3}$ & 23.08 & 23.22 & 316 & $150^{2}$ & 14.04 \\
\hline 10 & 7.72 & 7.74 & $0.15^{3}$ & 21.94 & 25.05 & 310 & $150^{2}$ & 13.78 \\
\hline 20 & 7.73 & 7.78 & $0.15^{3}$ & 22.02 & 22.17 & 390 & $150^{2}$ & 12.90 \\
\hline 30 & 7.80 & 7.92 & $0.15^{3}$ & 22.22 & 22.56 & 210 & $150^{2}$ & 9.30 \\
\hline 40 & 8.25 & 8.28 & $0.15^{3}$ & 23.50 & 23.59 & 200 & $150^{2}$ & 8.80 \\
\hline
\end{tabular}




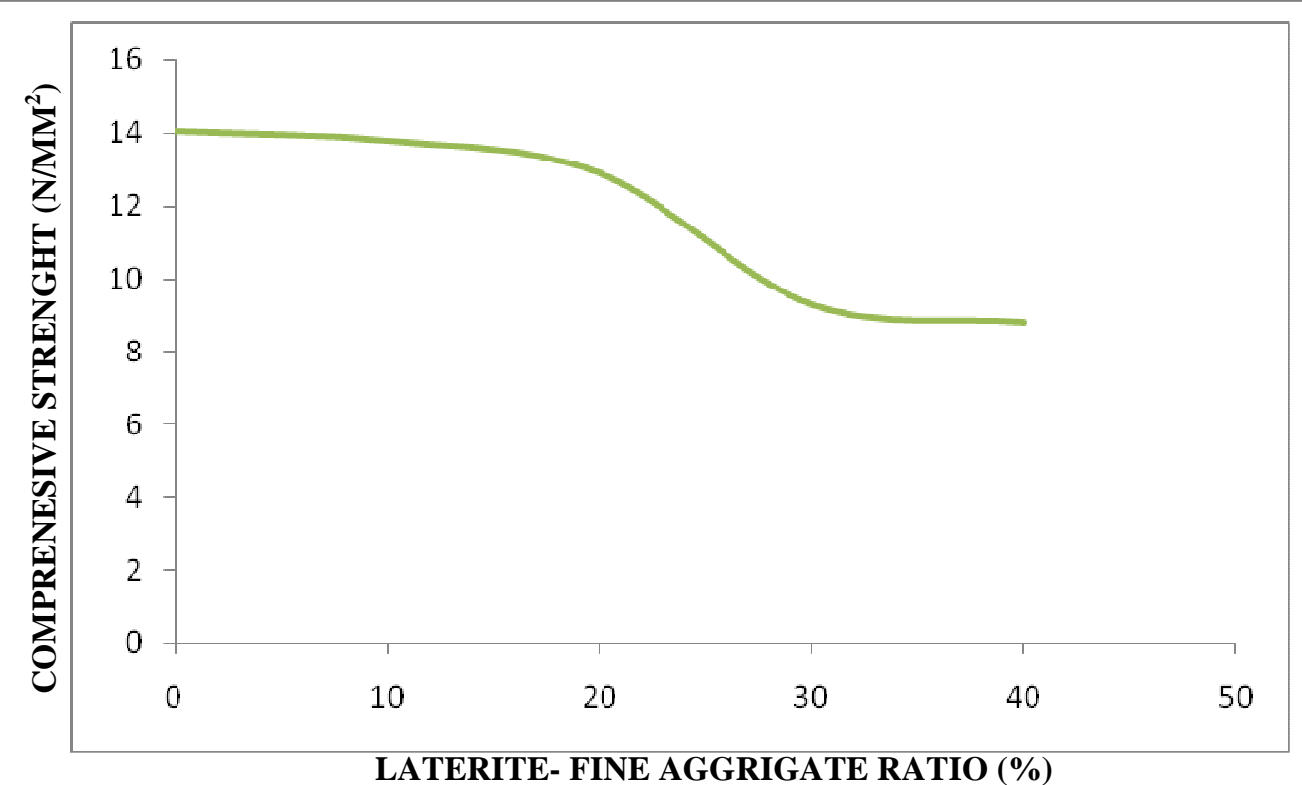

Chart 3: Effect of alternative wetting and drying on the compressive strength of laterized concrete.

Chart 2 shows the effect of magnesium sulphate on the compressive strength at the varying laterite-fine aggregate ratio. Chart 3 shows the effect of alternate wetting and drying on the compressive strength of laterized concrete at varying laterite-fine aggregate ratio, the chart also compares the compressive strength at the varying laterite-granite fine ratio for alternate wetting and drying with the maximum compressive strength for each percentage laterite-fine aggregate ratio variation.

\subsection{Discussion}

Considering the effect of temperature on the compressive strength of laterized concrete, it shows that for some of the laterized concrete cubes, especially those with laterite-fine aggregate ratio of 20 and $40 \%$ with concrete mix 1:2:4 at a curing age of 28 days, temperature had an appreciable impact on the compressive strength of the laterized concrete from 50 - $100 \mathrm{oC}$. For instance, the $20 \%$ laterite- fine aggregate ratio has the compressive strength increased from $12.40 \mathrm{~N} / \mathrm{mm} 2$ to $12.90 \mathrm{~N} / \mathrm{mm} 2,4.03 \%$ increase for a temperature range of $50-$ $100 \mathrm{oC}$ unlike the other percentage replacement, 10 and $30 \%$ laterite- fine aggregate ratio in which the compressive strength decreased after subjecting the cubes to increased temperature. The plain concrete with $0 \%$ laterite even had its compressive strength decreased from $14.22 \mathrm{~N} / \mathrm{mm} 2$ to $14.09 \mathrm{~N} / \mathrm{mm} 2,0.9 \%$ decrease for temperature range of $50-100 \mathrm{oC}$.

From chart 2, studying the effect of magnesium sulphate on the compressive strength of laterized concrete, it was found that the compressive strength of a $20 \%$ laterite-fine aggregate ratio when subjected to magnesium sulphate was $14.22 \mathrm{~N} / \mathrm{mm} 2$. Comparing this value with the compressive strength of same $20 \%$ laterite-fine aggregate ratio of a laterized concrete at temperature of $100 \mathrm{oC}, 12.90 \mathrm{~N} / \mathrm{mm} 2$, it shows that there was an increase in the strength by $10.23 \%$ when subjected to magnesium sulphate salt.

Also, studying the effect of alternate wetting and drying on the compressive strength of $0 \%$ laterite-fine aggregate ratio, the plain concrete, it was found that at temperature of $50 \mathrm{oC}$, compressive strength was $14.22 \mathrm{~N} / \mathrm{mm} 2$ while $14.04 \mathrm{~N} / \mathrm{mm} 2$ is found to be the result after it is subjected to alternate wetting and drying. It shows that there was a decrease in the strength by $1.28 \%$ when subjected to alternate wetting and drying. This was on the contrary at $20 \%$ laterite- sand ratio of laterized concrete where the compressive strength was maintained.

\section{CONCLUSIONS}

The influence of high temperature, chemical and alternating wet and dry condition on the compressive strength of laterized concrete has been investigated. It was found that for laterised concrete mix 1:2:4 and curing age of 28 days, with lateritefine aggregate ratio variation as a factor, $20 \%$ replacement of fine aggregate by laterite had a reasonable compressive strength for temperature applications up to $100 \mathrm{oC}$ whereas plain concrete and other percentage replacement suffered a reduction in compressive strength as the temperature increases. The reason for this could be due to some other inherent salts present in the laterite which may experience a breakdown in their internal structure when subjected to temperatures above $100 \mathrm{oC}$, thus leading to a reduction in the compressive strength of the laterized concrete, on the other hand, the increase in compressive strength for $20 \%$ replacement at temperature range of $100 \mathrm{oC}$ could be due to a 
gradual build up in the bond of the inherent salts present in the laterite which thus lead to a high bearing capacity of the laterized concrete.

Another conclusion drawn from the result of this study when laterized concrete is subjected to alternate wetting and drying, compressive strengths were as low as $9.30 \mathrm{~N} / \mathrm{mm} 2$. It implies that laterized concrete depreciates with time under the prevailing conditions (rainy and dry season) in the tropic. Similarly, when the same laterized concrete is subjected to magnesium sulphate (Mg2SO4), compressive strengths were as high as $14.22 \mathrm{~N} / \mathrm{mm} 2$. It implies that laterized concrete increases in strength when exposed to various metallic salts solution.

Optimum compressive strengths could be obtained at $20 \%$ laterized-fine aggregate ratio at temperature of $50-100 \mathrm{oC}$.

It is thereby recommended that for any concrete works in which laterite was to be used as a replacement or substitute for fine on coarse aggregate, the laterite should be carefully subjected to various test to ensure the suitability of the laterite for concrete strength. Also, the laterized concrete should not be exposed to constant rainy and dry season as it could result in reduction of its compressive strength. Otherwise, it could be subjected or exposed to magnesium sulphate salt $(\mathrm{Mg} 2 \mathrm{SO} 4)$ or any other metallic salt which may improve its compressive strength.

\section{REFERENCES}

[1] Hasniza B. H (2008). Effect of laterite soils as an aggregate substitute on the hydraulic force and compression strength of cube. Thesis, University Teknologi Malaysia.

[2] Lasisi, F and Osunade J. A(1984). Effect of grain size on the strength of cubes made from lateritic soils, building and environment, pergamon press, Great Britain.

[3] Oluwaseyi L. (2007). Influence of weather on the performance of laterized concrete. Journal of Engineering and Applied Sciences 2 (1); 129 - 135, 2007 @Medwell journals, 2007

[4] Ige O. A (2008). Science and Properties of Materials. Published by Sandbars Innovations Suite 62, Damin Plaza Ring Road, Ibadan

[5] British Standard Institute, (1996) BS 12: Portland Cement (ordinary and Rapid Heardening), BSI, London

[6] British Standard Institute, (1996) BS 5328: Part 1 and 2: Guide to specifying concrete and methods for specifying concrete mixes, BSI, London.

[7] Bwalya M. (2007). Utilization and improvement of lateric gravels in road bases. International Institute for Aerospace survey and Earth Sciences (ITC), Section Engineering Geology, Kanaahveg 3, 2628 EB, Delft, the Netherlands.

[8] Falade, F. (1994). Influence of water/cement ratios and mix proportions on workability and characteristics strength of concrete containing laterite fine aggregate, Building and Environment. Elsevier Science Great Britain.

[9] Osunade J. A. and Babalola, J. I. (1991). Effect of mix proportion and reinforcement sixe on the anchorage bond stress of laterized concrete, Building and Environment, Pergamon Press, Great Britain.

[10]Grattan-Bellew P. E (2001). Petrographic and technological methods for evaluation of concrete aggregates. William Andrew Publishing and Noyes Retrieved January 14, 2012 from www.knovel.com. 